\title{
Nitrate/nitrite poisoning in dairy cattle from the Midwestern Minas Gerais, Brazil
}

\author{
Daniel Amaral Gontijo ${ }^{1 *}$ Andressa Afonso Borges ${ }^{1}$ Flademir Wouters $^{2}$
}

${ }^{1}$ Faculdade de Medicina Veterinária (FAMEV), Universidade Federal de Uberlândia (UFU), Av. Pará, 1720, 38400-902, Uberlândia, MG,
Brasil. E-mail: daniel-gontijo@ufu.br. "Corresponding author. ${ }^{2}$ Departamento de Medicina Veterinária, Universidade Federal de Lavras (UFLA), Lavras, MG, Brasil.

\begin{abstract}
In a rural property of the Midwestern Minas Gerais, Brazil, three 2.5 to 3-year-old female bovines (7/8 Holstein x 1/8 Gir) weighing approximately $380 \mathrm{~kg}$ died after showing brownish colored mucosa of conjunctiva and vaginal vestibule, gray-bluish tongue, dyspnea, sialorrhea, tympany, and progression to sternal decubitus and death. In the macroscopic evaluation of one of the bovines, dark (chocolatecolored) blood of difficult coagulation, and intensely cherry-red skeletal and cardiac musculature were observed. Beyond that were observed brownish lungs, kidneys, liver, and encephalon, and all the stomach compartments were dilated due to large amounts of gas. In addition, the carcass exhaled a nitrous odor. The diphenylamine test and the nitrate dosage in the forage (Pennisetum purpureum, "elephant grass", Napier grass cultivar) used in feeding the bovines showed a high concentration of nitrate, allowing the diagnosis of nitrate/nitrite intoxication. The main factors leading to the poisoning were attributed to excessive fertilization of grass with bovine manure, the occurrence of a drought period followed by a rainy season, lack of adaptation of the bovines to a nitrate-rich diet, and a diet composed almost exclusively of elephant grass. This is the first report of spontaneous nitrate/nitrite poisoning in cattle in southeastern Brazil.

Key words: cattle diseases, plant poisoning, Pennisetum purpureum, nitrate/nitrite, soil fertilization.
\end{abstract}

\section{Intoxicação por nitrato/nitrito em bovinos leiteiros da região Centro-Oeste de Minas Gerais}

RESUMO: Em uma propriedade rural do Centro-Oeste de Minas Gerais, três fêmeas bovinas 7/8 Holandês e 1/8 Gir, com idade de 2 anos e 6 meses a 3 anos e peso de aproximadamente $380 \mathrm{~kg}$ vieram a óbito após manifestação clínica de mucosas conjuntivais e do vestíbulo vaginal amarronzadas, língua azul-acinzentada, dispneia, sialorreia, timpanismo e progressão para decúbito esternal e morte. Na necropsia de um dos animais, foram observados sangue escuro (cor de chocolate) e de dificil coagulação, músculos esqueléticos e cardíaco intensamente vermelhocereja, compartimentos gástricos distendidos por grande quantidade de gases e pulmões, rins, figado e encéfalo amarronzados. Além disso, o cadáver exalava odor nitroso. O teste de difenilamina e a dosagem de nitrato na forragem (Pennisetum purpureum, "capim-elefante", cultivar Napier) oferecida aos animais revelaram concentração elevada de nitrato na planta, com diagnóstico de intoxicação por nitrato/nitrito. Os principais fatores que levaram à intoxicação foram atribuidos à adubação excessiva do capim com esterco bovino; à ocorrência de um período de estiagem seguido por um período chuvoso; à falta de adaptação dos animais à alimentação rica em nitrato; e à dieta composta, quase exclusivamente, por capim-elefante. Este trabalho é o primeiro relato de intoxicação espontânea por nitrato/nitrito em bovinos no sudeste do Brasil.

Palavras-chave: doenças de bovinos, intoxicação por plantas, Pennisetum purpureum, nitrato/nitrito, adubação.

\section{INTRODUCTION}

The introduction of technologies that aim to increase the production of food for animals has contributed to optimize livestock performance. The quantity and the quality of forage directly interfere in the production of beef and dairy cattle (RENNÓ et al., 2008). Fertilization and irrigation enable increasing the production of high quality forage, guaranteeing high yields of milk per area and per animal, which can be optimized with concentrate supplementation (VILELA et al., 2006).

However, some rural producers without technical guidance make inappropriate use of these technologies, using manure without previous fermentation, or applying excessive nitrogen fertilization (MEDEIROS et al., 2003; RADOSTITS et al., 2007). A consequence of these two practices is the increase of nitrate content in the plants offered to animals as bulky food sources, which can lead to 
nitrate/nitrite intoxication (WRIGHT \& DAVISON, 1964; RADOSTITS et al., 2007; KOZLOSKI, 2009; JÖNCK et al., 2013).

In ruminants, microorganisms from stomach compartments transform dietary nitrate into nitrite and subsequently convert nitrite into ammonia for the synthesis of microbial protein (KOZLOSKI, 2009). The initial concentration of nitrate, the microbial flora and the diet of the animal, among other factors, interfere in the conversion of nitrite to ammonia, and there may be accumulation of nitrites (WANG et al., 1961; ALLISON 1978; KOZLOSKI, 2009).

Nitrite is toxic to erythrocytes because it converts hemoglobin into a type of dishemoglobin, the methemoglobin. This is an oxidized form of hemoglobin, whose $\mathrm{Fe}^{2+}$ from the heme group is oxidized to the ferric state $\left(\mathrm{Fe}^{3+}\right)$, which cannot bind to oxygen $\left(\mathrm{O}_{2}\right)$. In addition, an allosteric change occurs in the partially oxidized hemoglobin that generates a greater affinity between this protein and $\mathrm{O}_{2}$, making it difficult to release oxygen to tissues, and causing tissue anoxia (HAYMOND et al., 2005).

However, in controlled doses, nitrate in ruminants' diet can bring benefits. HUYEN et al. (2010) concluded that this ion can be used, as well as urea, as a source of nonprotein nitrogen for the synthesis of protein by ruminal microorganisms. Furthermore, nitrate can reduce the production of methane in stomach compartments by acting as an electron acceptor and decreasing the enteric production of $\mathrm{H}_{2}$, which is necessary for methanogenesis (ELLIS et al., 2008; LENG, 2008; NOLAN et al., 2010). The emission of methane gas into the atmosphere is one of the factors that contributes to global warming (PRIMAVESI et al., 2004), and ruminants' production is considered responsible for about $28 \%$ of the total annual emission of this gas (KLIEVE, 2009).

The aim of this work is to report an outbreak of nitrate/nitrite intoxication in dairy cattle from a farm in the West-Central region of Minas Gerais, Brazil.

\section{MATERIALS AND METHODS}

In a rural property near the cities of Bom Despacho and Moema, in Minas Gerais, Brazil, three of 18 animals from a paddock with 2.5- to 3-yearold female bovines (7/8 Holstein x 1/8 Gir) weighing approximately $380 \mathrm{~kg}$ died after an abrupt change in diet. Clinical examinations of affected animals and necropsy of one of these animals were performed.

The necropsy was performed immediately after death, and fragments of rumen, reticulum, abomasum, intestines, liver, spleen, kidneys, lungs, heart, brain, and skeletal muscle were collected, fixed in $10 \%$ formalin and sent to the Sector of Veterinary Pathology of the Universidade Federal de Lavras (UFLA). The samples were macroscopically evaluated, histologically processed, and examined under light microscopy.

The diphenylamine test was performed in elephant grass samples, and consists in adding one drop of the reagent solution $(0.5 \mathrm{~g}$ diphenylamine, $20 \mathrm{~mL}$ distilled water, and $80 \mathrm{~mL}$ concentrated sulfuric acid) to three drops from the plant extract on glass slides. The extract was obtained by manual pressure (TOKARNIA et al., 2012).

A $420 \mathrm{~g}$ sample of the grass was collected for nitrate dosage, repeating the same harvesting procedures made on the farm, i.e., cutting the entire plant close to the soil and chopping it in a forage machine. Then, the sample was placed in a Ziploctype plastic vacuum package, stored in a thermal bag with dry ice and sent to 3rlab Laboratory in Lavras, Minas Gerais.

\section{RESULTS AND DISCUSSION}

The poisoned heifers presented brownish colored mucosa of conjunctiva (Figure 1A) and vaginal vestibule (Figure 1B), gray-bluish tongue, dyspnea, sialorrhea, tympany, and progression to sternal decubitus and death. MEDEIROS et al. (2003) have also described dyspnea, sialorrhea, tympany in addition to decubitus, and death 30 minutes after decubitus in spontaneously intoxicated cattle. TOKARNIA et al. (2012) and JÖNCK et al. (2013) have also described brownish or cyanotic mucosa.

Two of three heifers died about one week after the abrupt diet exchange of maize silage (Zea mays) for elephant grass (Pennisetum purpureum), and the other one died about 20 days after the diet change. Moments before death, this animal presented stiffness in limbs and jaw, and pedaling movements. The supply of elephant grass was not interrupted after the two first deaths, since the cause had not been diagnosed yet. Diet was changed again only after the third death.

At necropsy, darkened blood (chocolatecolored; Figure 1C) of difficult coagulation, cherryred colored skeletal (Figure 1D) and cardiac (Figure 1E) musculature, stomach compartments dilated due to large amounts of gas, and lungs (Figure 1F), kidneys, liver and encephalon brownish-colored were observed. A strong nitrous odor was noted in the carcass during the necropsy, also described by 

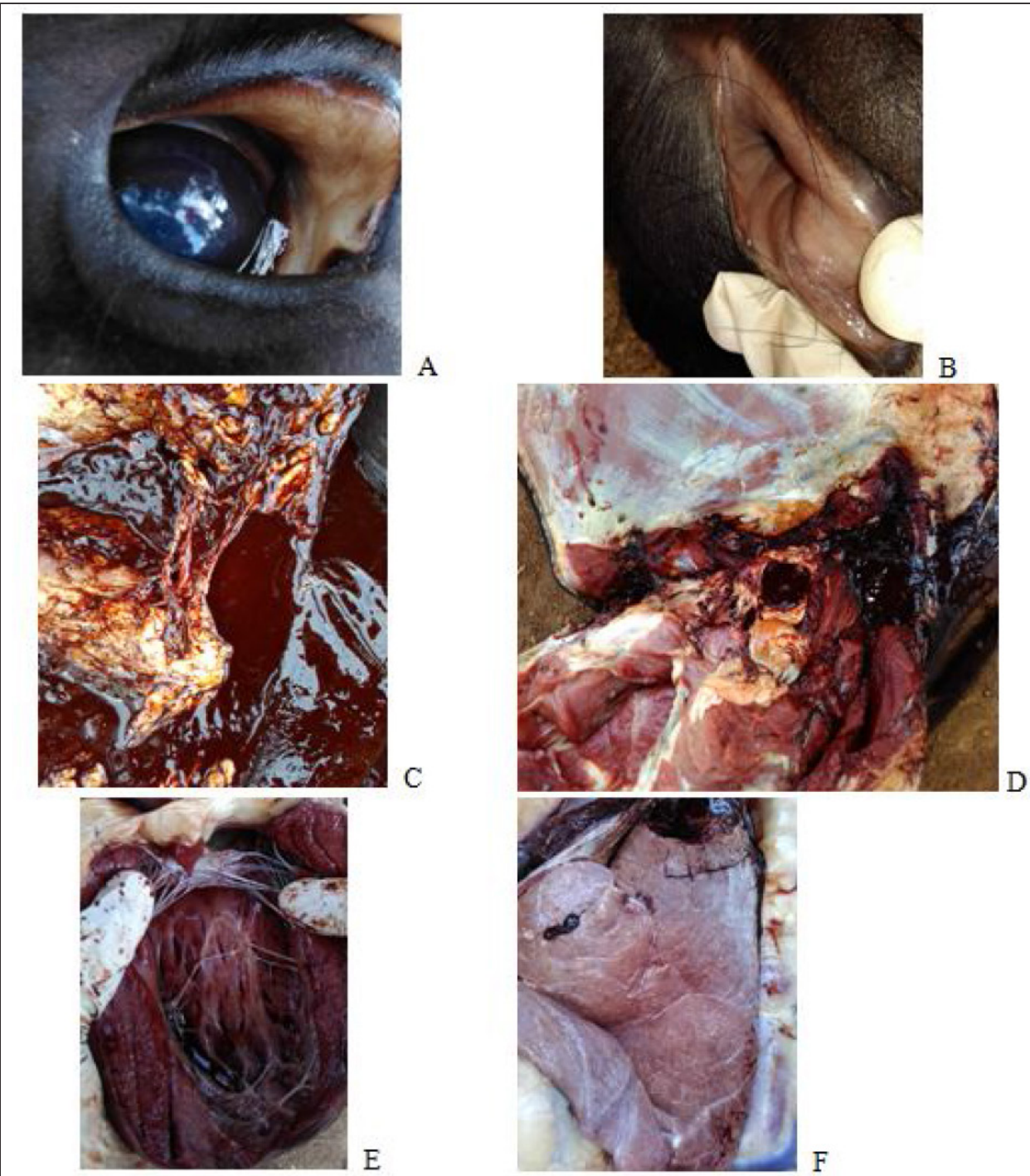

E
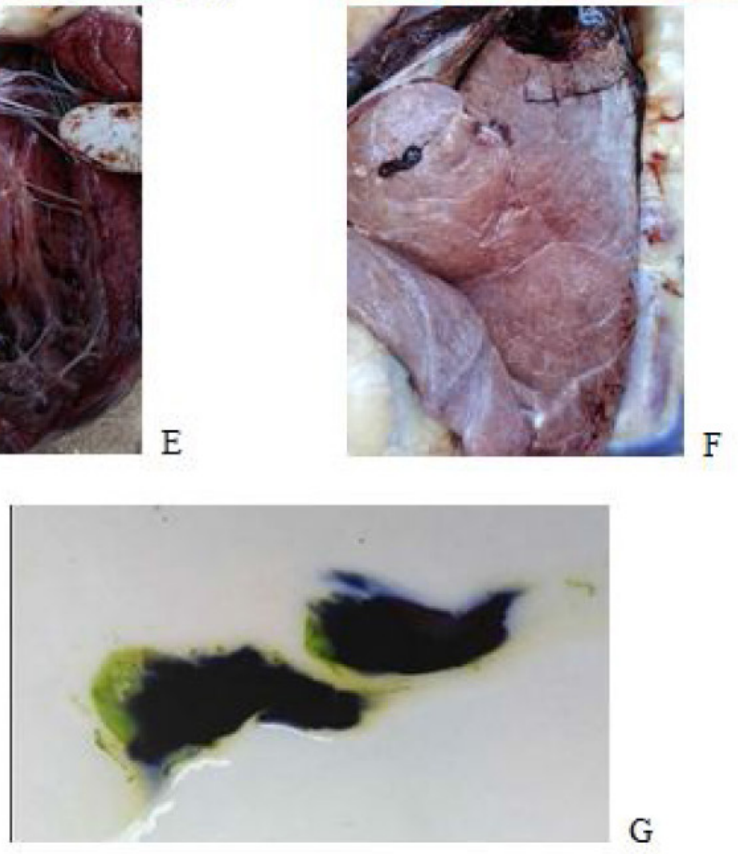

Figure 1 - Nitrate/nitrite poisoning in bovine. (A-F) Necropsy findings: (A) Brownish mucosa of conjunctiva; (B) Brownish mucosa of vaginal vestibule; (C) Chocolate-colored blood; (D) Cherry-like colored skeletal musculature; (E) Cherry-like colored myocardium; (F) Brownish lung; (G) Glass blade with positive result in diphenylamine test in forage (elephant grass) used to feed the cattle.

TOKARNIA et al. (2012). The necropsy findings of chocolate-colored and poorly clotted blood, and intensely red colored skeletal and cardiac musculature were compatible with those described by RADOSTITS et al. (2007), TOKARNIA et al. (2012), and JÖNCK et al. (2013). JÖNCK et al. (2013) have also observed 
brownish lungs and brain of cattle with spontaneous and experimental intoxication by nitrate/nitrite.

There were no histopathological alterations in fragments sent for analysis, which discards some diseases and reinforces the diagnosis of nitrate/ nitrite intoxication, which usually does not induce histological lesions (RADOSTITS et al., 2007; TOKARNIA et al., 2012).

The heifers were in a degraded pasture of Tifton 85 (Cynodon dactylon) and received forage supplementation consisting of elephant grass (whole plant) since about one week before the two first deaths. The elephant grass was chopped at around 11 a.m. and offered twice a day (around 1 p.m. and 8 p.m.); concentrate supplementation composed of ground corn and citrus pulp (around 1 p.m.) and another concentrate with ground corn, soybean meal, citrus pulp, mineral supplement provided mixed to concentrate in the ratio of $3: 100^{\mathrm{a}}$, agricultural urea, sulfur, and sodium bicarbonate (around 8 p.m.); mineral supplement for growth ${ }^{\mathrm{b}}$ once a day; water from a creek that passes through the farm, supplied at libitum in a water tank.

Three of 18 heifers died after the abrupt exchange of maize silage for chopped elephant grass (whole plant). The lack of adaptation of ruminal microbiota to nitrate, associated with diets rich in this ion, leads to excessive production of nitrites, because the ruminal microbiota reduces large amounts of nitrates to nitrites, which are five to six times more toxic than nitrates (ROGERS \& HOPE-CAWDERY, 1980). Nitrites are absorbed by rumen capillaries and reach the blood stream (LENG, 2008).

The way the plant is offered to animals also influences the amount of nitrate ingested. The plants, in natura, have a higher content of nitrates when compared to the same ensiled plant, because the fermentation process reduces considerably the levels of these ions. The distribution of nitrates in the forage is another factor that interferes with the amount of nitrates to which the animal has access, because the stem has a higher concentration of these ions in relation to the leaves. Thus, the cutting height of the plant is important, because the less stem is incorporated, the smaller the amount of nitrate intake (KAHN \& LINE, 2005).

The elephant grass plantation was lush. Due to the slope of the terrain, the crop was located below the premises where animals were milked and fed, so the water from rains and daily washing of the milking parlor carried cattle manure to the plantation, resulting in overfertilization of the grass. Besides that, application of bovine manure without previous treatment was made in the crop.
The intoxication occurred in a rainy period (November 2016 to January 2017), that followed a drought season (May to October 2016). The occurrence of a drought period followed by a rainy period is considered an important factor that results in the increase of nitrate concentration in the plants, causing an accelerated growth and absortion of toxic levels of nitrates (RIET-ALVARIZA, 1993; CHEEKE, 1998; RADOSTITS et al., 2007).

This paper is the first report of spontaneous nitrate/nitrite poisoning in cattle in southeastern Brazil. The first outbreak of this intoxication in cattle in Brazil was described by MEDEIROS et al. (2003) in the interior of Paraíba after ingestion of creeping rivergrass (Echinochloa polystachya) and elephant grass (Pennisetum purpureum). Other cases were reported in Santa Catarina, in oat (Avena sativa) and ryegrass (Lolium spp.) pastures by JÖNCK et al. (2013). Other forage species are already known to have a high nitrate content such as maize (Zea mays) and sorghum (Sorghum spp.), according to RADOSTITS et al. (2007).

Diphenylamine test and nitrate dosage in elephant grass were performed, and the results of these tests associated with clinical signs and epidemiological data allowed to conclude the diagnosis of nitrate/nitrite intoxication. The diagnosis of nitrate/nitrite intoxication is based on herd and feeding history, epidemiology, clinical signs, and results of complementary tests such as hemogasometry, methemoglobin dosage, anatomopathological examination, diphenylamine test, and nitrate dosage in grass and water (RADOSTITS et al., 2007; JÖNCK et al., 2013).

At diphenylamine test, a color change from green to deep blue (Figure 1G) occurred in less than ten seconds in sap drops extracted from the plant. The diphenylamine test, which is qualitative for the nitrate concentration, can be performed on blood samples, body fluids and pasture (RIET-ALVARIZA, 1993; MEDEIROS et al., 2003). In the forage extract, the change from green to deep blue in less than ten seconds means positive result, i.e. the nitrate concentration in the plant is high (RADOSTITS et al., 2007; JÖNCK et al., 2013).

Other grasses were not analyzed because the heifers received only elephant grass as bulky food source. Although they were in a pasture of Tifton 85, it was strongly degraded since the soil was poorly covered by the grass. Water was not tested for nitrates because all the animals of the property received water from the same source, a creek that passes through the farm, and only heifers consuming elephant grass were 
affected. The elephant grass comprised about $80 \%$ of total dry matter intake in this animal category, which received low-concentrate supplementation (about $20 \%$ of total dry matter), comparing with the cows.

The low-concentrate supplementation probably contributed to the nitrate/nitrite poisoning, since ruminal microbiota ability to detoxify nitrates and nitrites is energy-depending (VALLI, 2007).

The antidote for nitrate/nitrite poisoning is intravenous $1 \%$ methylene blue infusion at the dosage of 1 to $2 \mathrm{mg} / \mathrm{kg}$ live weight. Methylene blue has reducing power and acts by converting $\mathrm{Fe}^{3+}$ to $\mathrm{Fe}^{2+}$, and receiving an $\mathrm{H}^{+}$from NADPH (becoming leukotolene blue) and donating it to methemoglobin, which is converted to hemoglobin. Time to metabolize this drug is short, and the poisoned animal shows improvement within minutes after administration. The rapid response to the treatment is another form of diagnosis of the intoxication (RADOSTITS et al., 2007; JÖNCK et al., 2013). However, in this case, the treatment was not done due to the rapid evolution of the clinical condition and the lack of the antidote at the farm.

JÖNCK et al. (2013) described experimental and spontaneous intoxication in cattle, with nitrate concentrations ranging from 0.30 to $3.36 \%$ in dry matter in oat and ryegrass pastures. At one of the experimental cases, a $110 \mathrm{~kg}$ bovine died after consuming $90 \mathrm{~kg}$ of green oat with $3.36 \%$ of nitrate in 5 days. In another experimental case, a $272 \mathrm{~kg}$ bovine died after eating $4.64 \mathrm{~kg}$ of ryegrass hay with $2.33 \%$ of nitrate in 10 hours.

In the present report the nitrate dosage in elephant grass revealed $3965 \mathrm{ppm}(0.3965 \%)$, and the first two deaths occurred approximately 1 week after the beginning of the elephant grass supply, whereas the third death occurred after about 20 days. According to VOUGH et al. (2006), when the nitrate concentration in forage is between $3500 \mathrm{ppm}$ and $4000 \mathrm{ppm}$ it is necessary to limit the supply of the fodder to $25 \%$ of the total dry matter intake, however, the elephant grass composed about $80 \%$ of the total dry matter in the diet.

According to JÖNK et al. (2013), the amount of nitrate ingested and methemoglobin formed influences the period of time between disease progression and death. The amount of methemoglobin formed in each animal is variable, since it depends on the individual nitrate recycling rates in the rumen and on the drop in nitrite levels, reflecting different levels of nitrate tolerance presented by the animals (OZMEN et al., 2005).

Another factor that interferes in the period of time between disease progression and death is the amount of nitrate-rich forage ingested by each animal. According to HAFEZ \& BOISSOU (1975), the interactions between bovines result in hierarchical relations, in which, through disputes, the subordinate-dominant order is established. VALLAILLET et al. (2007), working with lactating dairy cows, found a longer time at the trough of cows with a high value in dominance ranking in the first 120 minutes after the feeding.

Thus, the social interactions established between animals determine that some dominate and therefore eat more than others. The amount of elephant grass ingested by each animal and the individualities in metabolism presented by each one explains the fact that the third death occurred about 20 days after the change in diet, while the first two deaths occurred about 1 week after the change.

Nitrate/nitrite intoxication should be differentiated from intoxication caused by hydrocyanic acid (HCN), according to RIETALVARIZA (1993) and RADOSTITS et al. (2007). Besides dyspnea and cyanotic mucosa (AMORIM et al., 2006), tympany, sialorrhea, decubitus and death (AMORIM et al., 2006; TOKARNIA et al., 2012) are clinical signs common to cyanide and nitrate/nitrite poisonings (MEDEIROS et al., 2003; TOKARNIA et al., 2012, JÖNCK et al., 2013).

However, blood is chocolate-colored in nitrate/nitrite poisoning (RADOSTITS et al., 2007; TOKARNIA et al., 2012; JÖNCK et al., 2013), whereas it is bright red in HCN intoxication (RADOSTITS et al., 2007). In the case of nitrate/ nitrite intoxication, the carcass exhales a nitrous odor (TOKARNIA et al., 2012) while an odor of almonds in cyanide poisoning is exhaled by the rumen content (RADOSTITS et al., 2007).

Cyanogenic plants are those that have hydrocyanic acid as active principle (AMORIM et al., 2006). Eleven species of livestock interest (Manihot glaziovii, Manihot piauhyensis, Cnidoscolus phyllacanthus, Sorghum halepense, Sorghum sudanense, Holocalyx glaziovii, Piptadenia macrocarpa, Piptadenia viridiflora, Prunus sellowii, Prunus sphaerocarpa, Passiflora foetida) were described by TOKARNIA et al. (2012) as cyanogenic plants, and tifton 68 (Cynodon nlemfuensis Vanderyst) by GALINDO et al. (2017).

In the present work, the blood of the necropsied animal was chocolate-colored, the carcass exhaled nitrous odor, and the ingested plant was elephant grass, which reacted positively in diphenylamine test, presented 3965ppm of nitrate in dry matter and it is not known to be a cyanogenic 
plant. Therefore, the picrosodic paper test for detection of hydrocyanic acid (TOKARNIA et al., 2012) was not performed.

The epidemiological data of abrupt exchange of bulk food source, the lack of adaptation of the bovines to the almost exclusive consumption of this grass, the fact that this forage specie is known for its high level of nitrate (MEDEIROS et al., 2003), the supply of nonensiled whole plant, the fertilization with large amounts of untreated bovine manure, and a long period without rain followed by high rainfall rates have contributed to the suspect of elephant grass offered to the animals as the cause of intoxication.

The intoxication occurred only in the heifers group, whose diet was almost exclusively composed of elephant grass, that corresponded to approximately $80 \%$ of the total dry matter intake. Cows, on the other hand, had access to a larger and less degraded pasture and received large amounts of concentrate, and the calves received milk, a little concentrate supplementation, and ate a small amount of the grass.

\section{CONCLUSION}

The clinical signs, necropsy findings, histopathological examination, epidemiological data, the positive diphenylamine test and the nitrate dosage in grass confirmed the nitrate/nitrite intoxication.

The nitrate concentration found in elephant grass was 3965ppm, and this fodder composed about $80 \%$ of the total dry matter intake of heifers. This is the first report of spontaneous nitrate/nitrite intoxication in cattle in southeastern Brazil.

The abrupt change in diet, with introduction of a bulky food source containing high nitrate levels, the overfertilization of elephant grass with untreated manure, and the occurrence of a drought period followed by a rainy season have constituted important epidemiological data for the poisoning.

\section{SOURCES OF ACQUISITION}

aCOoperfós NÚCLEO - COOPERBOM LTDA. (composition: min. 2,500 IU vitamin E; min. 750mg copper; min. 44mg cobalt; min. 100,000 IU vitamin D3; min. 3,000mg zinc; min. 45mg iodine; min. 30mg selenium; min. 3,000mg manganese; $\min . / \mathrm{max} .175$ to $225 \mathrm{~g}$ calcium; min. 450,000 IU vitamin A; max. 900mg fluorine; min. $70 \mathrm{~g}$ phosphorus; min. $20 \mathrm{~g}$ magnesium; min. $20 \mathrm{~g}$ sulfur; min. $70 \mathrm{~g}$ sodium; and min. $1,200 \mathrm{mg}$ sodic monensin per kg of product)

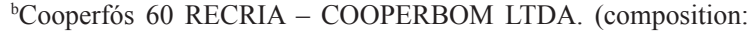
min./max. 80-130g calcium; min. 84mg cobalt; min. 956mg copper; min. $12.9 \mathrm{~g}$ sulfur; $\max .670 \mathrm{mg}$ fluorine; $\mathrm{min}$. $60 \mathrm{~g}$ phosphorus; $\mathrm{min}$. 59mg iodine; min. 12.9g magnesium; min. 3,825mg manganese; min. $42 \mathrm{mg}$ selenium,; min. $187 \mathrm{~g}$ sodium; and $\min .3,825 \mathrm{mg}$ zinc per kg of product).

\section{REFERENCES}

ALLISON, M.J. The role of ruminal microbes in the metabolism of toxic constituents from plants. In: KEELER, R. F. et al. Effects of poisonous plants on livestock. New York: Academic Press, 1978. p.101-118.

AMORIM, S.L. et al. Intoxication by cyanogenic plants in Brazil. Ciência Animal, Fortaleza, v.16, n.1, p.17-26, 2006. Available from: <http://www.uece.br/cienciaanimal/dmdocuments/ Artigo2.2006.1.pdf>. Accessed: Aug. 26, 2017.

CHEEKE, P.R. Natural Toxicants in Feeds, Forages, and Poisonous Plants. 2.ed. Danville: Interstate Publishers, 1998. 479p.

ELLIS, J.L. et al. Aspects of rumen microbiology central to mechanistic modelling of methane production in cattle. Journal of Agricultural Science, Toronto, v.146, p.213-233, 2008. Available from: <http://library.wur.nl/WebQuery/wurpubs/fulltext/25511>. Accessed: Mar. 22, 2017. doi: 10.1017/S0021859608007752.

GALINDO, C.M. et al. Spontaneous and experimental poisoning by tifton 68 (Cynodon nlemfuensis Vanderyst) in cattle. Pesquisa Veterinária Brasileira, Rio de Janeiro, v.37, n.5, p.441-446, 2017. Available from: < http://www.scielo.br/pdf/pvb/v37n5/1678-5150pvb-37-05-00441.pdf $>$. Accessed: Aug. 26, 2017. doi: 10.1590/ S0100-736X2017000500003.

HAFEZ, E.S.E.; BOUISSOU, M.E. The behaviour of cattle. In: HAFEZ, E.S.E. The Behaviour of Domestic Animals. Baltimore: Williams \& Wilkins, 1975. p.247-296.

HAYMOND, S. et al. Laboratory assessment of oxygenation in methemoglobinemia. Clinical Chemistry, Baltimore, v.51, n.2, p.434-444, 2005. Available from: <http://clinchem.aaccjnls. org/content/51/2/434>. Accessed: Mar. 22, 2017. doi: 10.1373/ clinchem.2004.035154.

HUYEN, L.T.N. et al. Nitrate as fermentable nitrogen supplement to reduce rumen methane production. Livestock Research for Rural Development, Cali, v.22, n.8, 2010. Available from: $<$ http:// www.lrrd.org/lrrd22/8/huye22146.htm>. Accessed: Mar. 22, 2017.

JÖNCK, F. et al. Spontaneous and experimental poisoning by nitrate/nitrite in cattle fed Avena sativa (oat) and/or Lolium spp. (ryegrass). Pesquisa Veterinária Brasileira, Rio de Janeiro, v.33, n.9, p.1062-1070, 2013. Available from: <http://dx.doi. org/10.1590/S0100-736X2013000900003>. Accessed: Mar. 20, 2017. doi: 10.1590/S0100-736X2013000900003.

KAHN, C.M.; LINE, S. The Merck Veterinary Manual. 9. ed. Whitehouse Station: Merck \& Co., 2005. 2712p.

KLIEVE, A.V. Microbial contribution to and amelioration of enteric methane emissions from domestic herbivores. Australia Microbiology, Osborne Park, v.30, n.2, p.82-84, 2009. Available from: <http://dx.doi.org/10.1071/MA09082>. Accessed: Mar. 21, 2017. doi: 10.1071/MA09082.

KOZLOSKI, G.V. Bioquímica dos ruminantes. 2.ed. Santa Maria: UFSM, 2009. 216p.

LENG, R.A. The potential of feeding nitrate to reduce enteric methane production in ruminants. A Report to the Department of Climate Change, Commonwealth Government of Australia, 
Canberra, 2008. 82p. Online. Available from: <http://www. penambulbooks.com/Downloads/Leng-Final $\% 20$ Modified $\% 20$ \%2017-9-2008.pdf>. Accessed: Mar. 22, 2017.

MEDEIROS, R.M.T. et al. Nitrate and nitrite poisoning in cattle caused by the ingestion of Echinochloa polystachya and Pennisetum purpureum in the semiarid region of the state of Paraíba. Pesquisa Veterinária Brasileira, Rio de Janeiro, v.23, n.1, p.17-20, 2003. Available from: <http://dx.doi.org/10.1590/ S0100-736X2003000100004>. Accessed: Mar. 20, 2017. doi: 10.1590/S0100-736X2003000100004.

NOLAN, J.V. et al. Effects of dietary nitrate on fermentation, methane production and digesta kinetics in sheep. Animal Production Science, Victoria, v.50, n.8, p.801-806, 2010. Available from: <http://www.mekarn.org/MSc_CTU/literature/2010\%20 APS\%20Nolan\%20nitrate\%20mitigates\%20methaneAN09211. pdf>. Accessed: Mar. 22, 2017. doi: 10.1071/AN09211.

OZMEN, O. et al. Pathological and toxicological investigations of chronic nitrate poisoning in cattle. Toxicological and Environmental Chemistry, New York, v.87, n.1, p.99-106, 2005. Available from: <http://www.tandfonline.com/doi/ abs/10.1080/02772240400007104>. Accessed: Aug. 1, 2017. doi: $10.1080 / 02772240400007104$

PRIMAVESI, O. et al. Dairy cattle enteric methane measured in Brazilian tropical conditions. Pesquisa Agropecuária Brasileira Brasília, v.39, n.3, p.277-283, 2004. Available from: <http://dx.doi. org/10.1590/S0100-204X2004000300011>. Accessed: Mar. 21, 2017. doi: 10.1590/S0100-204X2004000300011.

RADOSTITS, O.M. et al. Veterinary Medicine: A textbook of the diseases of cattle, horses, sheep, pigs and goats. 10.ed. Philadelphia: Saunders, 2007. 2065p.

RENNÓ, F.P. et al. Bioeconomic evaluation of feeding strategies in milk production systems. 1. Production per animal and per area. Revista Brasileira de Zootecnia, Viçosa, v.37, n.4, p.743753, 2008. Available from: <http://dx.doi.org/10.1590/S151635982008000400022>. Accessed: Mar. 21, 2017. doi: 10.1590/ S1516-35982008000400022.

RIET-ALVARIZA, F. Intoxicação por nitratos e nitritos. In: RIETCORREA, F. et al. Intoxicações por Plantas e Micotoxicoses em Animais Domésticos. Pelotas: Hemisfério Sul, 1993. Cap.15, p.291 - 297.

ROGERS, P.A.M.; HOPE-CAWDERY, M.J. Monensin, ketosis and nitrate toxicity in cows. Veterinary Record, Londres, v.106, p.311-312, 1980. Available from: <http://dx.doi.org/10.1136/ vr.106.14.311>. Accessed: Mar. 22, 2017. doi: 10.1136/vr.106.14.311.

TOKARNIA, C.H. et al. Plantas Tóxicas do Brasil para Animais de Produção. 2.ed. Rio de Janeiro: Helianthus, 2012. 586p.

VAL-LAILLET, D. et al. The concept of social dominance and the social distribution of feeding-related displacements between cows. Applied Animal Behaviour Science, Amsterdam, v.111, p.158 172, 2007. Available from: <http://s173-183-201-52.ab.hsia. telus.net/Inetpub/wwwroot/DairyScience/Resources/Research/ AABS111/AABS111_158.pdf>. Accessed: Aug. 15, 2017. doi: 10.1016/j.applanim.2007.06.001.

VALLI, V.E.O. Hematopoietic System. In: MAXIE, G.M. (Ed) Jubb, Kennedy and Palmer's Pathology of Domestic Animals. 5.ed. Edinburgh: Saunders Elsevier, 2007. v.3. Cap. 2, p. 260-262.

VILELA, D. et al. Performance of Holsteins cows on coastcross pasture. Revista Brasileira de Zootecnia, Viçosa, v. 35, n. 2, p. 555-561, 2006. Available from: <http://www.scielo.br/pdf/\%0D/ rbz/v35n2/a31v35n2.pdf>. Accessed: Aug. 15, 2017. doi: 10.1590/ S1516-35982006000200031.

VOUGH, L.R. et al. Nitrate Poisoning of Livestock: Causes and Prevention. Extension Extra Archives, Paper 114, South Dakota State University (SDSU), 2006. 4p. Online. Available from: $<$ http://openprairie.sdstate.edu/cgi/viewcontent.cgi?article $=1113 \&$ context=extension_extra>.Accessed: Mar. 22, 2017.

WANG, L.C. et al. Metabolism of nitrate by cattle. Biochemical Journal, Auckland, v. 81, n. 237, p. 237-242, 1961. Available from: <https://doi.org/10.1042/bj0810237>. Accessed: Mar. 22, 2017. doi: 10.1042/bj0810237.

WRIGHT, M.J.; DAVISON, K.L. Nitrate accumulation in crops and nitrate poisoning in animals. Advances in Agronomy, New York, v.16, p.197-274, 1964. Available from: <http://dx.doi. org/10.1016/S0065-2113(08)60025-5>. Accessed: Mar. 20, 2017. doi: $10.1016 / \mathrm{S} 0065-2113(08) 60025-5$. 